\title{
Incubation period of Hemileia vastatrix in coffee plants in Brazil simulated under climate change
}

\author{
Raquel Ghini $^{1 *}$, Emília Hamada ${ }^{1}$, Mário José Pedro Júnior ${ }^{2} \&$ Renata Ribeiro do Valle Gonçalves ${ }^{3}$
}

${ }^{1}$ Embrapa Meio Ambiente, C.P. 69, 13820-000, Jaguariúna, SP; ${ }^{2}$ IAC/APTA/SAA, Campinas, SP; ${ }^{3}$ Faculdade de Engenharia Agrícola, Unicamp, C.P. 6011, 13083-875 Campinas, SP

Autor para correspondência: Raquel Ghini (raquel@ cnpma.embrapa.br)

Data de chegada: 10/11/2009. Aceito para publicação em: 14/07/2010.

\section{ABSTRACT}

1659

Ghini, R.; Hamada, E.; Pedro Júnior, M.J.; Gonçalves, R.R.V. Incubation period of Hemileia vastatrix in coffee plants in Brazil simulated under climate change. Summa Phytopathologica, v.37, n.2, p.85-93, 2011.

Risk analysis of climate change on plant diseases has great importance for agriculture since it allows the evaluation of management strategies to minimize future damages. This work aimed to simulate future scenarios of coffee rust (Hemileia vastatrix) epidemics by elaborating geographic distribution maps using a model that estimates the pathogen incubation period and the output from three General Circulation Models (CSIRO-Mk3.0, INM-CM3.0, and MIROC3.2.medres). The climatological normal from 1961-1990 was compared with that of the decades 2020s, 2050s and 2080s using scenarios A2 and B1 from the IPCC. Maps were prepared with a spatial resolution of $0.5 \times 0.5$ degrees of latitude and longitude for ten producing states in Brazil. The climate variables used were maximum and minimum monthly temperatures. The maps obtained in scenario A2 showed a tendency towards a reduction in the incubation period when future scenarios are compared with the climatological normal from 1961-1990. A reduction in the period was also observed in scenario B1, although smaller than that in scenario A2.

Keywords: Coffea arabica, coffee rust, future scenarios, global warming.

\section{RESUMO}

Ghini, R.; Hamada, E.; Pedro Júnior, M.J.; Gonçalves, R.R.V. Simulação dos efeitos das mudanças climáticas sobre o período de incubação de Hemileia vastatrix em cafeeiro no Brasil. Summa Phytopathologica, v.37, n.2, p.85-93, 2011.

A análise de risco das mudanças climáticas globais sobre doenças de plantas é de grande importância para o setor agrícola, pois permite a avaliação de estratégias de manejo para minimizar prejuízos futuros. O presente trabalho teve por objetivo simular os cenários futuros de epidemias de ferrugem do cafeeiro (Hemileia vastatrix), pela elaboração de mapas de distribuição geográfica usando um modelo que estima o período de incubação do patógeno e dados de três modelos climáticos globais (CSIRO-Mk3.0, INM-CM3.0, and MIROC3.2.medres). O período da normal climatológica de 1961-
1990 foi comparado com as décadas de 2020, 2050 e 2080, usando cenários A2 e B1 do IPCC. Mapas foram preparados com resolução espacial de 0,5 X 0,5 graus de latitude e longitude para dez Estados produtores do Brasil. As variáveis climáticas utilizadas foram temperaturas máximas e mínimas mensais. Os mapas obtidos no cenário A2 permitem verificar que há tendência de redução do período de incubação, quando se compara os cenários futuros com o clima de 1961-1990. No cenário B1, também foi observada redução do período, porém nota-se que é inferior ao cenário A2.

Palavras-chave adicionais: Coffea arabica, ferrugem do cafeeiro, cenários futuros, aquecimento global.

The Fourth Assessment Report (Working Group I) of the Intergovernmental Panel on Climate Change (IPCC) stated that the global atmospheric concentration of carbon dioxide, methane and nitrous oxide has increased as a result of human activities since 1750 and exceeds the pre-industrial values determined from ice cores spanning many thousands of years (11). As a result, the global surface temperature has increased approximately $0.2^{\circ} \mathrm{C}$ per decade in the last three decades and $0.8{ }^{\circ} \mathrm{C}$ in the past century (9). The effects would continue for centuries due to the timescales associated with climate processes and feedbacks, even if greenhouse gas concentrations were to be stabilized.

IPCC (10) published a set of emission scenarios in the Special Report on Emission Scenarios (SRES) designed to serve as a basis for assessment of climate change (from 1990 to 2100). Each scenario represents a specific quantitative interpretation of one of four storylines (A1, A2, B1, and B2). Each storyline represents different demographic, social, economic, technological and environmental developments. General Circulation Models (GCM), run using these emission scenarios, have been developed to assess the potential impacts of global climate change.

Assessment of climate change impacts on plant diseases is receiving increasing attention as adaptation strategies can come only from improved knowledge (6). Bergot et al. (2) have used a GCM to predict a range expansion of Phytophthora cinnamomi, over 100 years, by modeling the temperature of phloem in infected trees to evaluate overwintering probabilities. In order to assess the impacts of climate change 
on the pressure of downy mildew infections in grapes, an empirical disease model developed by Salinari et al. (15) for the area of study was run using climate change scenarios generated by two GCM. Ghini et al. (7) estimated probable impacts of climate change on the black Sigatoka disease (Mycosphaerella fijiensis) of banana in Brazil, through the elaboration of distribution maps using data from six GCM, and observed that there will be a reduction in the favorable area for the disease in the country.

Coffee rust, caused by Hemileia vastatrix, is a major disease of coffee plants, which constitutes an important commodity for Brazil and other tropical countries. The incubation period - the time interval between inoculation and the appearance of symptoms - is a critical stage of the pathogen's biological cycle. When environmental conditions occur at an optimum, the pathogen can invade the plant up to the maximum of its potential, resulting in a reduction in incubation periods and more severe epidemics. The aim of this paper was to simulate future scenarios of coffee rust epidemics under climate change, by elaborating geographic distribution maps using a model of the pathogen incubation period and the output from three GCM (CSIRO-Mk3.0, INM-CM3.0 and MIROC3.2.medres). The climatological normal from 19611990 was compared with that of decades 2020s, 2050s, and 2080s in scenarios A2 and B1.

\section{MATERIALAND METHODS}

Maximum and minimum mean monthly temperatures were obtained from the DDC-IPCC (http://www.ipcc-data.org/sres/ gcm_data.html). In order to characterize the normal climate, information was taken into account regarding the climatological normal of the period from 1961 to 1990 . For future climate, three GCM that present data for these climatic variables were used: CSIRO-Mk3.0 (CSIRO Atmospheric Research, Australia), INMCM3.0 (Institute for Numerical Mathematics, Russia), MIROC3.2. and medres (Center for Climate System Research, Japan). The future scenarios used were A2 and B1, focused on the 2020s (period between 2011 and 2040), 2050s (period between 2041 and 2070) and 2080s (period between 2071 and 2100). Valverde \& Marengo (17) described the alterations for Brazilian climate under these scenarios.

The data files were obtained from DDC-IPCC containing monthly maximum and minimum temperature data for the climatological normal from 1961-1990 and future periods for each GCM and years from 2011 to 2100 , for both scenarios A2 and B1. The original data, comprising the South-American continent, were organized in a computer system for management of climate data, developed using the database management system Firebird 2.0, the Object Pascal language of Delphi software, and the tool for data manipulation IBExpert, according to the latitudes and longitudes defined by each model. The information pertaining to the Brazilian territory was selected for the following steps:

The Idrisi 32 GIS (Geographic Information System) was used to prepare georeferenced maps. Because of different spatial resolutions of the GCM (CSIRO-Mk3.0: $1.875^{\circ} \times 1.865^{\circ}$, INMCM3.0: $5.0^{\circ} \times 4.0^{\circ}$, and MIROC3.2.medres: $2.81252^{\circ} \times 2,7904^{\circ}$ ), the data were interpolated by the Square Inverse Distance method, resulting a final spatial resolution of $0.5^{\circ} \times 0.5^{\circ}$ in latitude and longitude.

The monthly maximum and minimum temperatures for the future scenarios were obtained by the average of the three GCM, using the GIS spatial analysis tools (arithmetic operation). Based on these maps for scenarios A2 and B1 in the climatological normal from 1961-1990 and future periods (2020, 2050, and 2080), maps were obtained showing estimated coffee rust incubation periods. This was accomplished by using the model developed by Moraes et al. (14), in which the incubation period is estimated based on the air temperature extremes [incubation period $=103.01-0.98$ (maximum temperature) - 2.10 (minimum temperature)]. The data in the obtained maps were classified into categories with incubation period intervals of 10 days. The areas corresponding to the states of Bahia (BA), Espírito Santo (ES), Goiás (GO), Mato Grosso (MT), Mato Grosso do Sul (MS), Minas Gerais (MG), Paraná (PR), Rio de Janeiro (RJ), Rondônia (RO), and São Paulo (SP) were selected from the georeferenced maps due to the importance of these regions for the coffee-growing activity in Brazil (Figure 1). A mask outlining the states was applied onto the maps.

To compare $H$. vastatrix incubation period observed in field experiments in the climatological normal period from 1961-1990 with the estimates obtained for 2080 in scenario A2, graphs were obtained for four regions. The data used were obtained by Moraes et al. (14), in the regions of Campinas (SP, longitude: $47.0^{\circ}$ west, latitude: $22.8^{\circ}$ south, and 673 m elevation), Monte Alegre do Sul (SP, longitude: $46.7^{\circ}$ west, latitude: $22.7^{\circ}$ south, and $777 \mathrm{~m}$ elevation), and Pindorama (SP, longitude: $49.0^{\circ}$ west, latitude: $21.2^{\circ}$ south, and 562 m elevation), and by Kushalappa \& Martins (12) in Viçosa (MG, longitude: $42.9^{\circ}$ west, latitude: $20.7^{\circ}$ south, and 689 m elevation).

\section{RESULTS AND DISCUSSION}

A tendency toward a reduction in $H$. vastatrix incubation period was observed in all future scenarios studied in relation to 1961-1990 climatological normal (Figures 2, 3, 4, and 5). This change will be more pronounced over the years, i.e., the maps obtained for 2080 show the shortest incubation periods due to global warming intensification if severe mitigation measures are not adopted to reduce greenhouse gas emissions.

The maps obtained for scenario A2 show more pronounced incubation period reductions than those obtained for scenario B1. The former scenario is characterized by high projections of both population and greenhouse gas emissions from the present to 2100 , resulting in more pronounced impacts than those obtained in B1. Scenario A2 family describes a very heterogeneous world. The underlying theme is self-reliance and preservation of local identities. Fertility patterns across regions converge very slowly, which results in a continuously increasing population. Scenario B1 family describes a convergent world, with the same global population as A1, but with more rapid changes in economic structures toward a service and information economy (10).

In general, incubation periods predicted for 2080 were shorter than those determined in experiments conducted under field conditions in the regions studied by Moraes et al. (14) and Kushalappa \& Martins (12) (Figure 6). Data obtained by Figueiredo et al. (3) for coffee-growing regions in the state of São Paulo also indicate higher values than those predicted for the future scenario. Results from these field studies conducted during the climatological normal period from 1961-1990 demonstrate this tendency for a shortened disease cycle. The distribution of the disease over the 


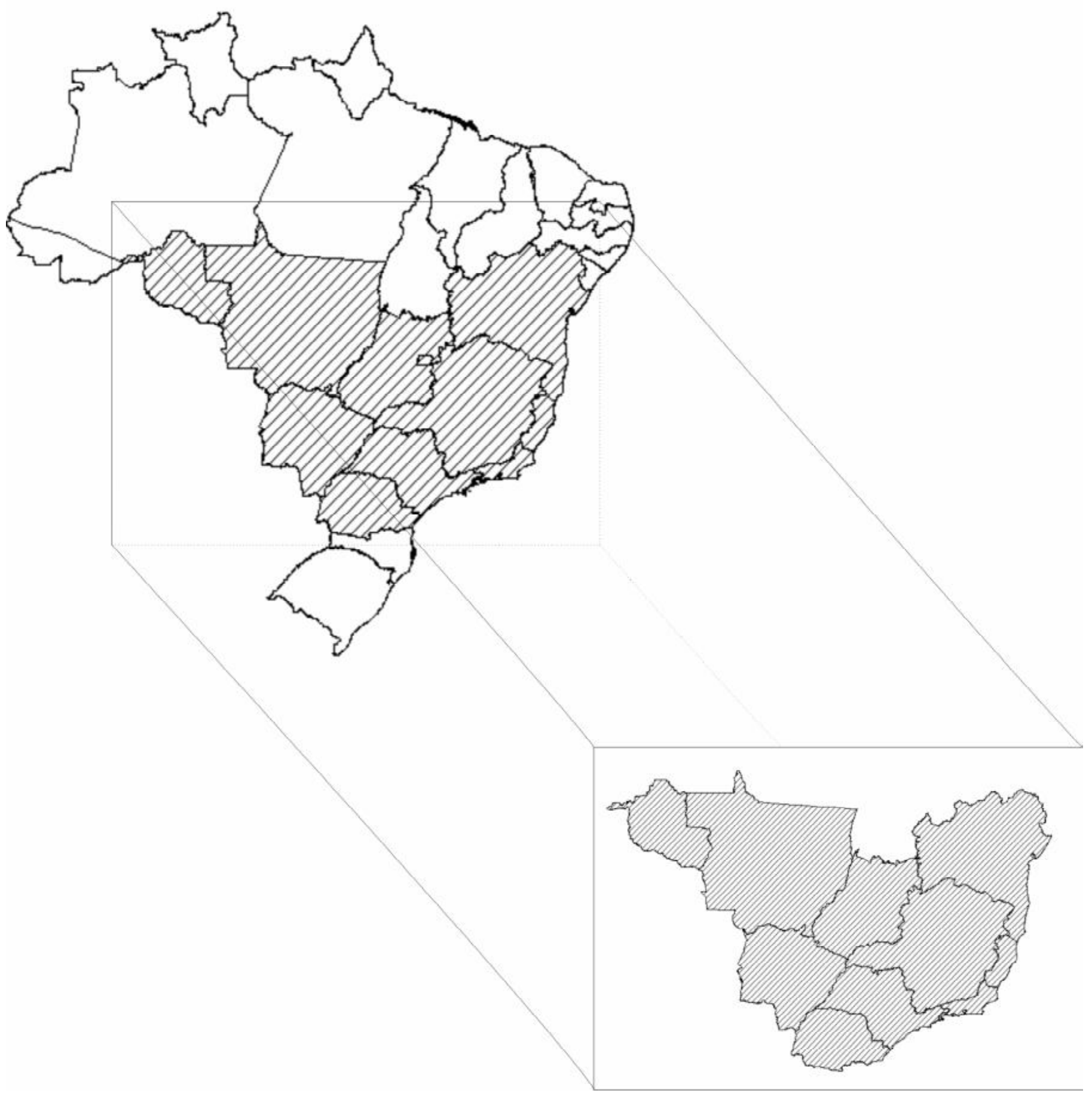

Figure 1. Location of selected coffee-producing states in Brazil.

months of the year should not undergo any changes since the shortest incubation periods still occur during the summer, while the longest ones occur during the winter in the future scenarios (Figures 2, 3, 4, and 5).

Climate change will affect the agroclimatic zoning, production and costs of the coffee crop. Results obtained by Gay et al. (5) comparing present and future expected coffee production suggest that changes in temperature and precipitation could cause a reduction of up to $34 \%$ in coffee production in Veracruz, Mexico, by the year 2020. For Brazil, according to Assad et al. (1), a reduction in suitable coffee-growing areas greater than $95 \%$ is expected in GO, MG and SP, and about $75 \%$ in PR in case of a temperature increase of $5.8{ }^{\circ} \mathrm{C}$. However, these results assume that all physiological characteristics of the crop will remain the same for the varieties analyzed; that the ideal condition for the economic development of the crop is a mean annual temperature between $18{ }^{\circ} \mathrm{C}$ and $23{ }^{\circ} \mathrm{C}$; in addition, a high fixed temperature increase value was adopted. However, Hamada et al. (8) concluded that using fixed average temperature increases resulted in an underestimation of the number of cycles of coffee leaf miner (Leucoptera coffeella) in the future, compared to the adoption of temperature increases that vary spatially and temporally, as in the 


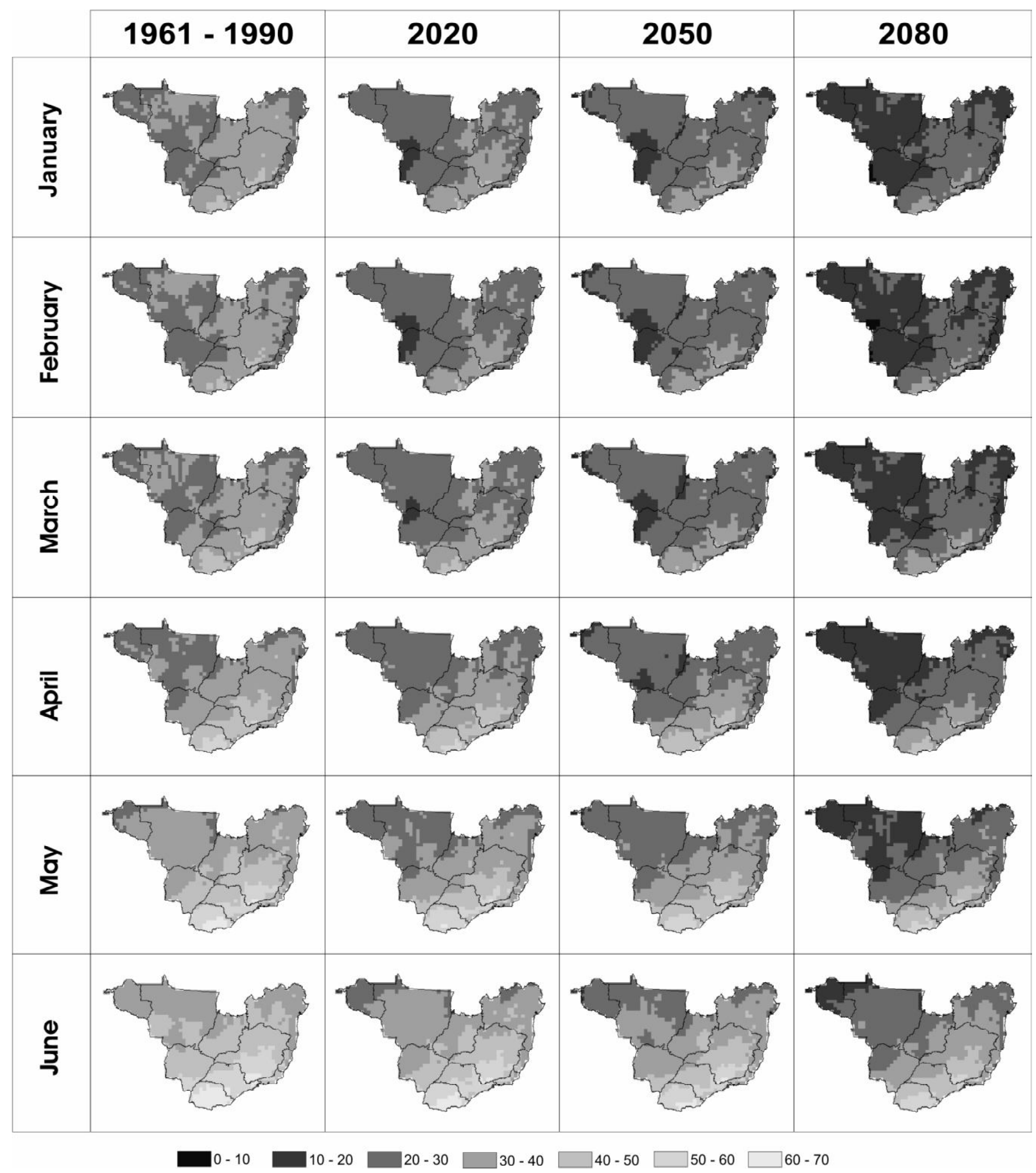

Figure 2. Maps of Hemileia vastatrix incubation periods (days) in coffee plants from January to June for the climatological normal from 1961-1990 and future climates $(2020,2050$, and 2080) in scenario A2. 


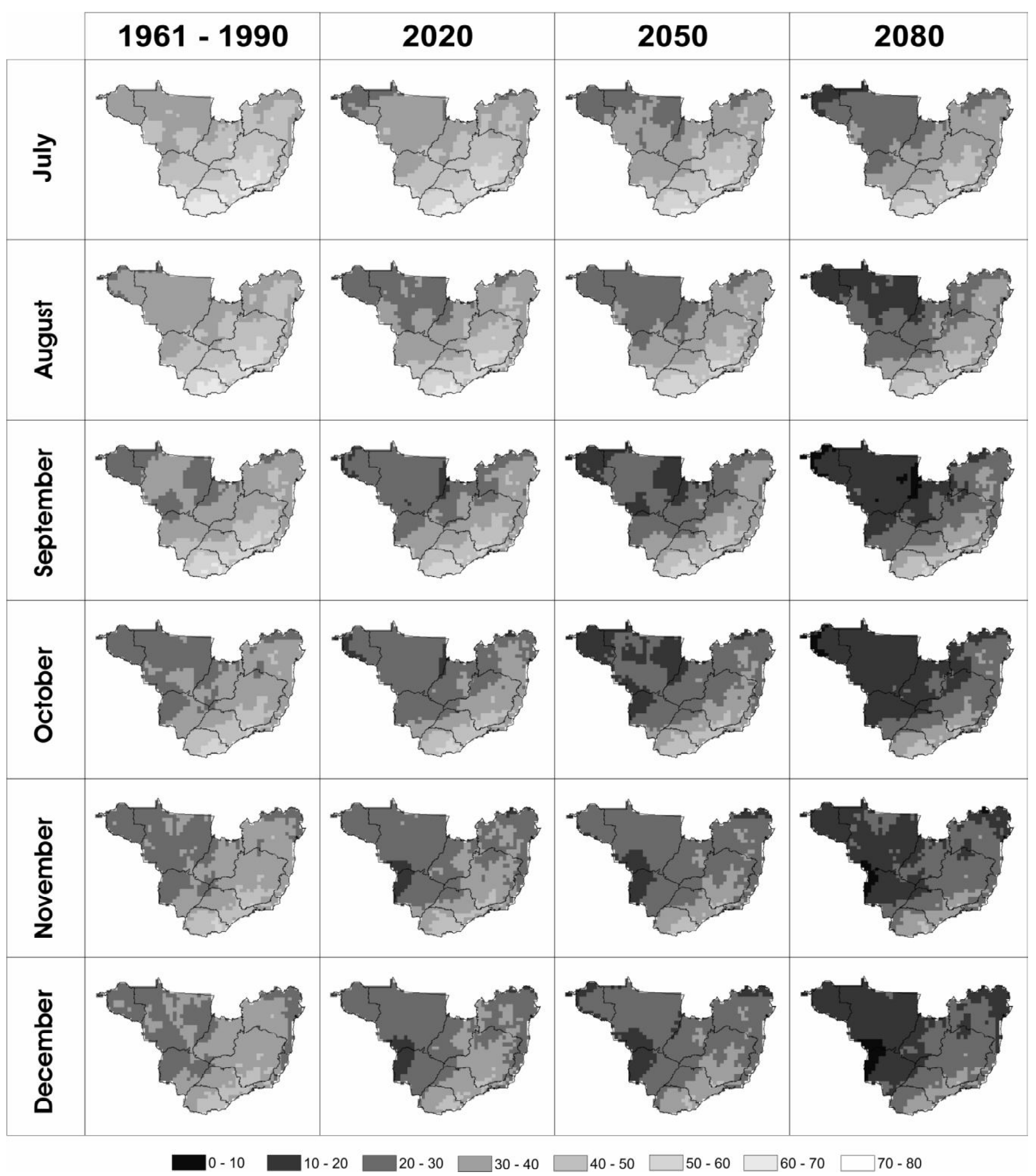

Figure 3. Maps of Hemileia vastatrix incubation periods (days) in coffee plants from July to December for the climatological normal from 1961-1990 and future climates $(2020,2050$, and 2080) in scenario A2. 


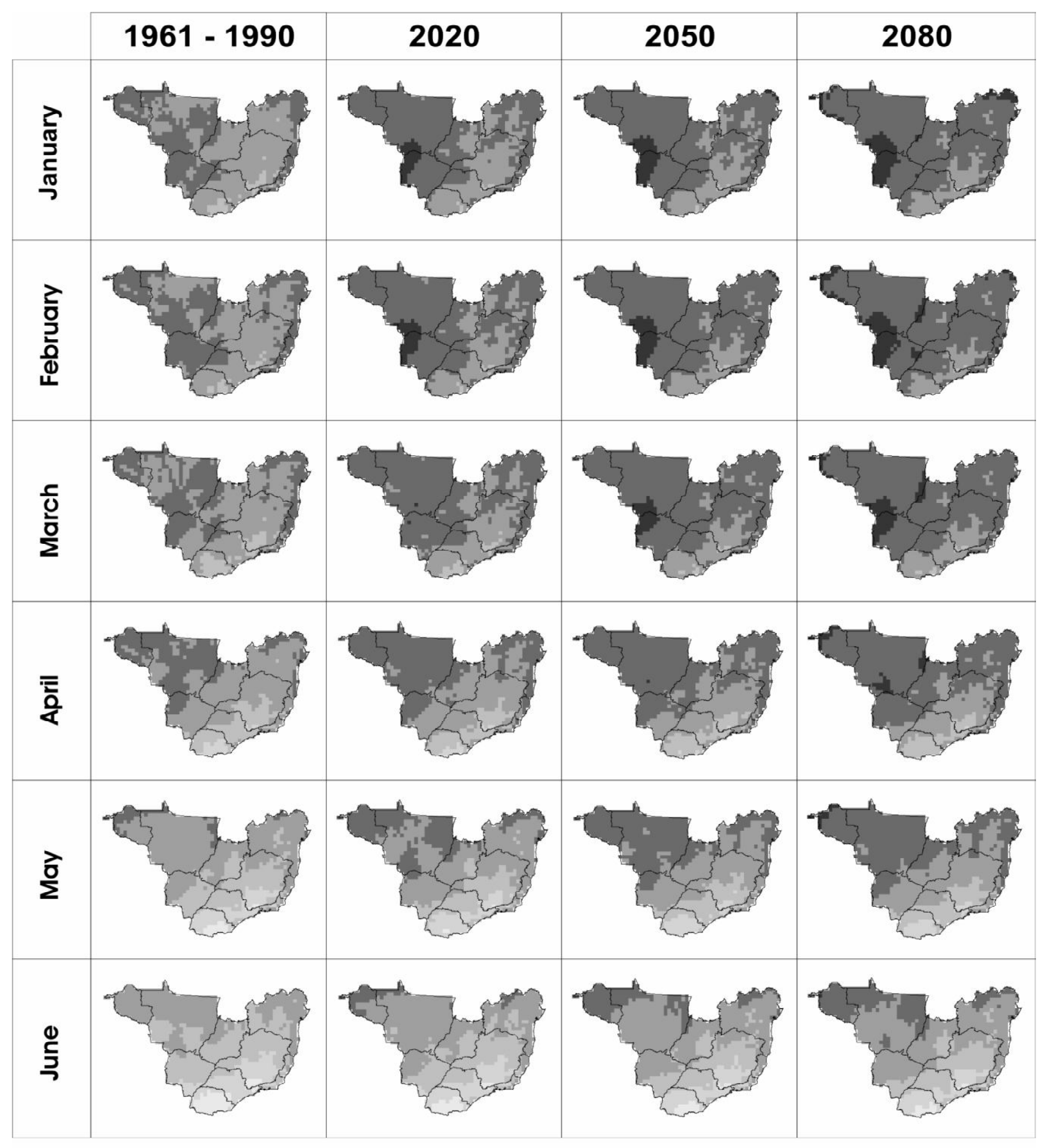

$10-20 \square 20-30 \square 30-40 \square 40-50 \square-60-60 \square 60-70$

Figure 4. Maps of Hemileia vastatrix incubation periods (days) in coffee plants from January to June for the climatological normal from 1961-1990 and future climates $(2020,2050$, and 2080) in scenario B1. 


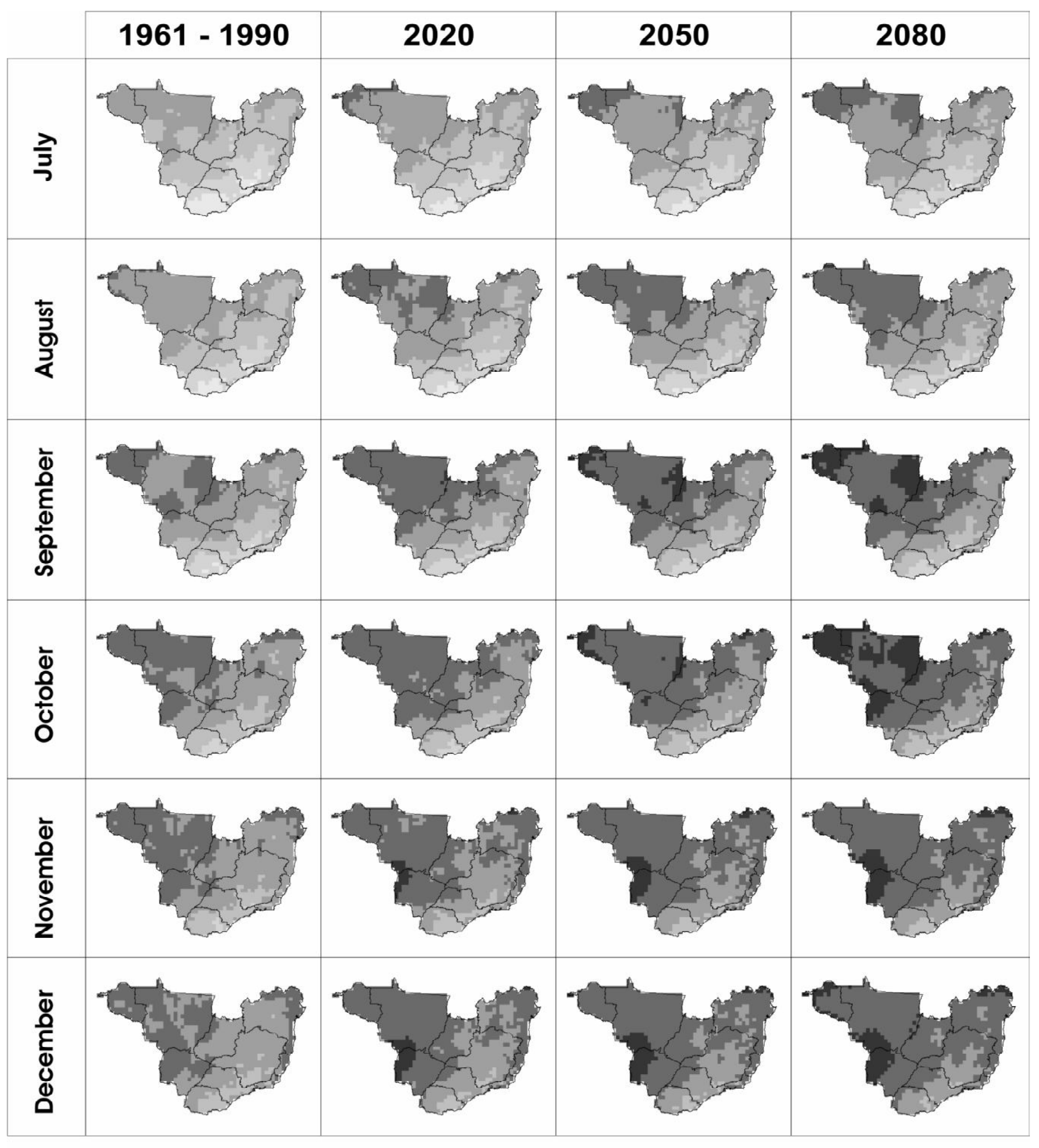

$$
10-20 \square 20-30
$$$$
30-40
$$$$
40-50
$$$$
50-60
$$$$
60 \text { - } 70
$$$$
70-80
$$

Figure 5. Maps of Hemileia vastatrix incubation periods (days) in coffee plants from July to December for the climatological normal from $1961-1990$ and future climates $(2020,2050$, and 2080) in scenario B1. 


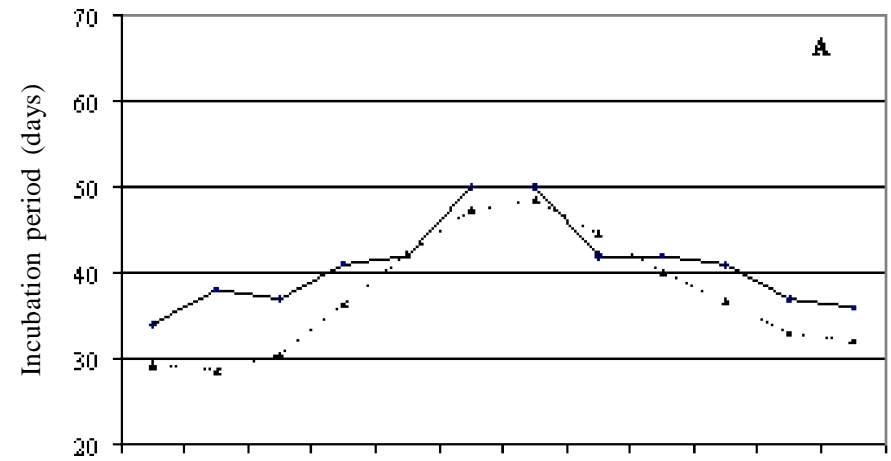

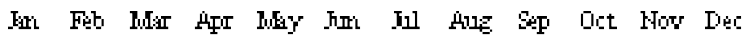

$\rightarrow$ Obsered (Moraes at al., 1976) + 2080-A2

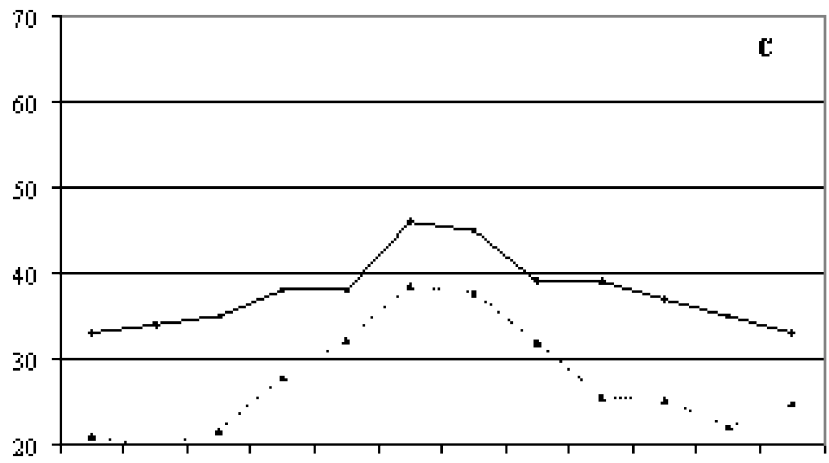

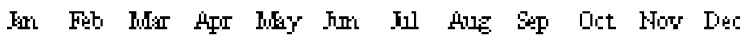

十 Obsered (Moras at al, 1976) + 2080 - A2

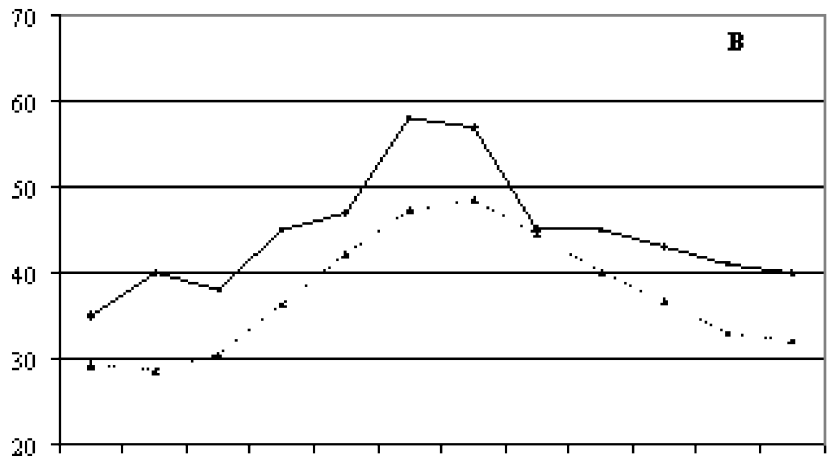

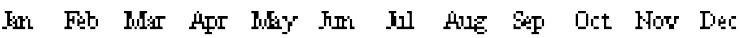
一 Obsered (Moraes et 11,1976$)+2080-\mathrm{A2}$

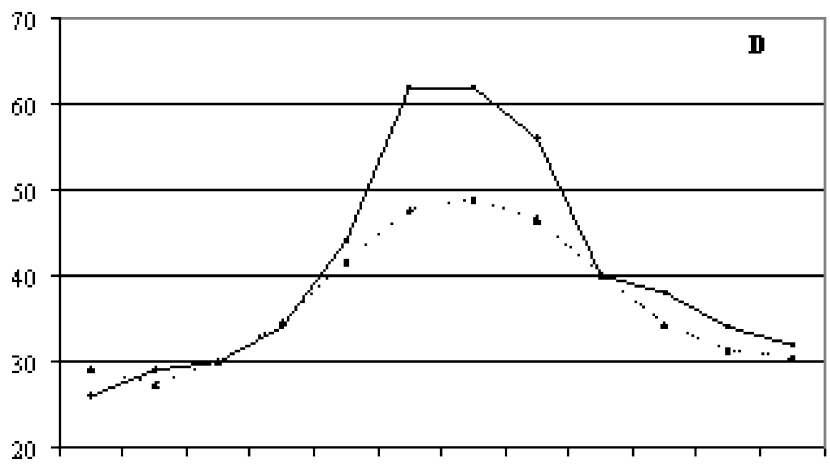

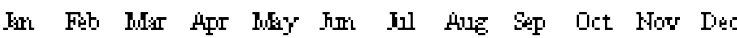

+ Obsered (Kishalappa o Martine, 1980) + $2080-\mathrm{A2}$

Months

Figure 6. Incubation periods of Hemileia vastatrix in coffee plants observed by Moraes et al. (15) and Kushalappa \& Martins (14) and estimated for 2080 in scenario A2 for the regions of Campinas (A), Monte Alegre do Sul (B), Pindorama (C), and Viçosa (D).

present work by the use of GCM.

However, there are several uncertainties with the application of models for predicting climate change effects on plant diseases. Regional climatic models to predict future scenarios would allow the use of more detailed information about the climate and would reduce uncertainties about the results, whose efforts are presently being carried out at a worldwide level (13). In addition, the time scales of the climatic models available are related to monthly means; however, it is known that pathogen-host interactions occur at time scales often shorter than 24 hours. The low temporal and spatial resolutions of GCM impair the evaluation of biological responses, such as the development of diseases, which require daily or even hourly information. One of the most significant challenges is to link biological-process model requirements to the availability of climate models, under long-term approaches $(4,16)$.

Other climatic variables, in addition to those of the used incubation period model, which will also be affected by climate change, might play important roles at different stages of the disease cycle and affect the occurrence of epidemics. The potential for adaptation by plants and pests is another complicating factor that is often ignored in models. Despite the limitations of the results obtained, this work adopts a methodology still infrequently employed in plant disease studies and calls the attention to potential climate change impacts on the occurrence of an important disease for Brazilian agriculture, demonstrating the need of defining public policies targeted at mitigating and/or adapting to a new climate scenario.

\section{ACKNOLEDGMENT}

To CNPq for providing a scholarship to the authors.

\section{REFERENCES}

1. Assad, E.D.; Pinto, H.S.; Zullo Jr, J.; Ávila, A.M.H. Impacto das mudanças climáticas no zoneamento agroclimático do café no Brasil. Pesquisa Agropecuária Brasileira, Brasília, v. 39, n. 11, p. 1057-1064, 2004.

2. Bergot, M.; Cloppet, E.; Perarnaud, V.; Deque, M.; Marcais, B.; Desprez-Loustau, M.L. Simulation of potential range expansion of oak disease caused by Phytophthora cinnamomi under climate change. Global Change Biology, New York, v. 10, n. 9, p. 1539-1552, 2004.

3. Figueiredo, P.; Mariotto, P.R.; Silveira, A.P; Geraldo Júnior, C. Período de incubação, evolução de Hemileia vastatrix Berk \& Br. e a utilização da equação de Rayner em alguns municípios cafeeiros do estado de São Paulo. O Biológico, São Paulo, v. 43, n. 12, p. 32-40, 1977.

4. Garrett, K.A.; Dendy, S.P.; Frank, E.E.; Rouse, M.N.; Travers, 
S.E. Climate change effects on plant disease: genomes to ecosystems. Annual Review of Phytopathology, Palo Alto, v. 44, p. 489-509, 2006.

5. Gay, C.; Estrada, F.; Conde, C.; Eakin, H.; Villers, L. Potential impacts of climate change on agriculture: a case of study of coffee production in Veracruz, Mexico. Climatic Change, Berlin, v. 79, n. 3/4, p. 259-288, 2006.

6. Ghini, R. Mudanças climáticas globais e doenças de plantas. Jaguariúna: Embrapa Meio Ambiente, 2005.

7. Ghini, R.; Hamada, E.; Gonçalves, R.R.V.; Gasparotto, L.; Pereira, J.C.R. Análise de risco das mudanças climáticas globais sobre a sigatoka-negra da bananeira no Brasil. Fitopatologia Brasileira, Lavras, v.32, n.3, p.197-204, 2007.

8. Hamada, E; Ghini, R.; Gonçalves, R.R.V. Efeito da mudança climática sobre problemas fitossanitários de plantas: metodologias de elaboração de mapas. Engenharia ambiental, Espírito Santo do Pinhal, v. 3, n. 2, p. 73-85, 2006.

9. Hansen, J.; Sato, M.; Ruedy, R.; Lo, K.; Lea, D.W.; MedinaElizade, M. Global temperature change. PNAS, Palo Alto, v. 103, p. 14288-14293, 2006.

10. INTERGOVERNMENTAL PANEL ON CLIMATE CHANGE. Emissions scenarios: summary for policymakers. Geneva, 2000. $20 \mathrm{p}$.

11. INTERGOVERNMENTAL PANEL ON CLIMATE CHANGE. Climate change 2007: the physical science basis. Geneva,
2007. 996 p.

12. Kushalappa, A.C.; Martins, C. P. Incubation periods for Hemileia vastatrix on coffee in Viçosa, Minas Gerais. Fitopatologia Brasileira, Brasília, v. 6, n. 1, p. 177-183, 1980.

13. Marengo, J.A. Mudanças climáticas globais e seus efeitos sobre a biodiversidade: caracterização do clima atual e definição das alterações climáticas para o território brasileiro ao longo do século XXI. Brasília: MMA, 2006. 212 p.

14. Moraes, S.A.; Sugimori, M.H.; Ribeiro, I.J.A.; Ortolani, A.A.; Pedro Jr., M.J. Período de incubação de Hemileia vastatrix Berk et Br. em três regiões do estado de São Paulo. Summa Phytopathologica, Piracicaba, v. 2, n. 2, p. 32-38, 1976.

15. Salinari, F.; Giosue, S.; Tubiello, F.N.; Rettori, A.; Rossi, V.; Spanna, F.; Rosenzweig, C.; Gullino, M.L. Downy mildew (Plasmopara viticola) epidemics on grapevine under climate change. Global Change Biology, New York, v. 12, n. 7, p. 1299-1307, 2006 .

16. Scherm, H.; van Bruggen, A. H. C. Global warming and nonlinear growth: how important are changes in average temperature? Phytopathology, St. Paul, v. 84, n. 2, p. 1380-1384, 1994.

17. Valverde, M.C.; Marengo, J. A. Mudanças na circulação atmosférica sobre a América do Sul para cenários futuros de clima projetados pelos modelos globais do IPCC AR4. Revista Brasileira de Meteorologia, v. 25, p. 125-145, 2010. 